\title{
Conflict in World Heritage Sites of Kathmandu Valley: A Case Study on the Conservation of Private Houses in Three Durbar Squares
}

- Monalisa Maharjan monalisamaharjan@gmail.com

Conflict between heritage management authorities and the local residents has been critical to sustainable management of the World Heritage Sites (WHS) in Kathmandu Valley. This paper attempts to find out the reasons of such conflict by analyzing the facets of prevalent non-compliance of rules and regulations in Kathmandu Valley's three World Heritage Sites: Hanuman Dhoka, Patan and Bhaktapur Durbar Squares. This is a qualitative analysis of perceptions, understanding and interests of the local people and the heritage management authorities. The paper also reviews the existing national and international policy provisions on conservation of WHS and makes special notes about the conservation of private houses in the WHS.

Cases were selected using snow-ball sampling technique. Structured interviews were conducted with key informants including concerned government officials and the local residents. The findings include such reasons of non-compliance of WHS regulations as overlapping and unclear roles of multiple institutions involved in the management of the WHS, lack of public participation in decision making, inadequate economic incentives to locals, ineffective implementation of compliance mechanisms.

\section{Introduction}

Kathmandu valley is a cultural hub and also Nepal's pride in international arena. Historical palaces, buildings, shrines and temples which display brilliant architectural craftsmanship make the valley of outstanding universal value. The UNESCO declared the valley a World Heritage Site in 1979 under criteria iii, iv and vi of UNESCO's operational guidelines among nine 
criteria [Department of Archaelogy (DoA), 2007]. The valley was listed in the UNESCO World Heritage Site as a single site comprising of seven monument zones. These include three historical palaces of Malla kings namely Hanuman Dhoka Durbar Square (Kathmandu), Patan Durbar Square, Bhaktapur Durbar Square, two Buddhist shrines i.e. Boudhanath and Swoyambhu Mahachaitya, and two Hindu shrines i.e. Changunarayan and Pashupatinath (Jenkins et. al., 2006). The cluster of vernacular houses, open spaces, urban landscape and other edifices like stone waterspouts, open platforms and traditional rest houses added to make the valley a unique heritage site (Amatya, 2007) .

Because of the closed policy adopted by the then rulers, Nepal was not exposed to the outside world until the establishment of democracy in 1951 AD. Thenafter, Nepal became known to the world (Levy, 1992). The exposure brought high literacy rates, and increased inflow of tourists. Also, with modernization brought boom of western concrete buildings in place of the traditional city (Hutt, 2010). The western influence increased more after the people's movement and establishment of multiparty democracy in $1990 \mathrm{AD}$ as new buildings with the new materials were used excessively (Amatya, 2007).

In 2003, Kathmandu Valley was kept in the World Heritage Site in Danger list. The main reason shown by UNESCO was the loss of urban fabric. International Council on Monuments and Sites (ICOMOS) State of Conservation Report (1998) stated,

The single overriding issue in protecting the integrity of the KVWHS is the control of damaging and illegal development. With few exceptions, the principal religious and public monuments are secure and require only normal maintenance. However, the traditional houses and commercial buildings, which form their essential setting are at great risk and are subject to extreme pressure. If redevelopment continues at the present rate and is not curbed by effective development 
controls, the authenticity of the WH site will be so severely damaged as to compromise its outstanding universal value. (UNESCO, 1999 pp: 3)

Though most of the monuments were in good conditions, traditional houses started to lose their unique architecture for which Kathmandu Valley was known for. The main reasons for this were excessive urbanization and haphazard development.

The preliminary census report of 2011 shows Kathmandu's population growth by 60.93 percent compared to Nepal's population growth, 14.99 percent, in a decade. The increase in urban pressure is also a major factor in deterioration of KVWHS. This swelling of population in the valley is creating urban pressure leading to the ripple effect in the heritage sites too (CBS, 2011). The Durbar Squares are losing their aesthetic value with haphazard construction of multi-storey buildings in their surroundings. Encroachment and illegal construction of buildings and lack of facilities of water and sewage management and other public utilities are converting these places into slums. Many of the old houses in Kathmandu Valley have the comparable quality of royal palaces, but the house owners do not value such houses. They rather prefer to build new houses with modern facilities demolishing the old ones (UNESCO, 2006).

Built heritage of the Valley is also linked to the day to day life of the people. Once these built heritages are lost, they can never be retrieved as each house is different from the other and has its own uniqueness. These heritages are major destinations for tourists visiting Nepal, and contribute to macro-economic stability of the country. Despite importance of these cultural and built heritages, adequate attention has not been given by the government towards their conservation. There are regulatory mechanisms which are not complied with. Many organizations and individuals are working towards the conservation, but they are far from achieving desired results. 
This paper studies on conservation of private houses which contribute to a major part in traditional urban fabric of the world heritage. The three monument zones, the palaces of erstwhile Malla kings - Hanuman Dhoka Durbar Square, Patan (Mangalbazar) Durbar Square and Bhaktapur (Layaku) Durbar Square - have similar urban settings, with similar problems and threats. I have documented common and diverging perceptions and positions on conversation of the WHS from the authorities and the local residents of the three studied monument zones. I review the national and international rules and regulations on conservation of WHS and their compliance in the studied sites. This study identifies areas of conflict and collaboration among the public authorities and local residents of the three monument zones. Finally, it makes few recommendations to strengthen collaboration between the authorities and local residents for sustainable management of the WHS in the Kathmandu valley.

\section{Literature Review}

Convention concerning the protection of the world cultural and natural heritage held in 1972 has stated that the cultural and natural heritage are increasingly threatened with destruction not only by the traditional causes of decay but also by changing social and economic conditions (UNESCO, 1972). The analysis report prepared by ICOMOS in 2005 revealed that the lack of adequate management and development pressures are clearly the strongest threats to WHS. Global socio-economic transformation and homogenization in culture have brought serious problems to the vernacular structures all around the world due to transformation in physical form and fabric along with the ways of their use, understanding and traditions associated (ICOMOS, 1999).

Pradhananga and Landorf (2008) reported the rapid urban development as a result of social, economical and political transformation which caused the loss of heritage values in the Kathmandu Valley. From 1993, in every convention, the World Heritage Committee repetitively recommended putting 
KVWHS in the danger list, with some guidelines - 15 recommendations in 1993 and 55 time-bound action plans in 1998 - for their further improvement (UNESCO, 2004). Despite these, process for improvement in KVWHS was negligible. Later in 2003, it was kept in WHS in the danger list (DoA, 2007).

The divergent interests of people with demands for modern facilities like land-fill sites and mobile telephone masts, often environmentally sensitive lead to the conflict in the conservation as the definitions of 'heritage' are mainly focused on preservation (McManus, 1997). Upreti has pointed that the rapid changes in the society also lead to conflict as conflict is just a clash of interests (Upreti, 2004).

Dijkgraaf, with the analysis of four heritage sites in the developing countries, stated that even UNESCO and international experts recognize the importance of cultural heritage but local inhabitants do not. Local people perceive that their daily struggle for survival is the prime focus. The conflict of interests is a significant threat to WHS particularly in the developing countries. Methods of conservation, maintenance and management of sites in developing areas of the world also differ greatly from those employed in the developed world as the developing world is mostly faced with lack of funds and that of technical as well as management experts (Dijkgraaf, 2003).

Different heritage sites have got different social and political settings, histories, and stakeholders, so different management strategies should be adopted. Even with the different strategies it should have the benefit of incentive distribution, relationship building through dialogue, and stakeholders' participation for empowerment and monitoring (Edroma, 2003).

Vienne Memorandum emphasizes on the all-level participation forming interdisciplinary team of experts and professionals, policy makers, urban planners, city developers, architects, conservationists, property owners, investors and concerned 
citizens, as well as have the mutual understanding to preserve the urban heritage while considering the modernization and development of society in a culturally and historically sensitive manner (UNESCO, 2005). The conservation of the built vernacular heritage must be carried out by multidisciplinary expertise while recognizing the inevitability of change and development, and the need to respect the community's established cultural identity (ICOMOS, 1999). UNESCO operational guidelines also emphasize on all-level participation from the time of nomination of site to WHS (UNESCO, 2008).

\section{Methodology}

In this dissertation qualitative research methodology has been adopted. The study focused on assessing converging and diverging perceptions, positions and interests of various stakeholders, particularly the heritage management authorities and the local residents on conservation of the WHS.

Study Sites: The study is conducted in three courtyards or durbar squares of KVWHS. All the three durbars have similar urban settings, which have palaces of Malla kings as the center of attractions. From the Malla Period these Durbars have been of high importance politically and economically. Being the King's Palaces, most of the traditional ceremonies happen in these areas or at least start from these areas as the focal point of celebration.

Sample Design: Three study sites were selected using purposive sampling. In all the three sites, conflict events were selected using snow-ball sampling method. Snowball sampling is a nonprobability sampling technique that is used by researchers to identify potential subjects in studies where subjects are hard to locate.

Data Collection: In this research, data collected through primary and secondary sources helped shape the research. Published and unpublished literatures relevant to the study have 
been reviewed. For the primary data collection, different tools like key informant interviews, case studies, focused group discussion, photographs, and observations were used. Heritage experts, site managers, DoA officials, locals, entrepreneurs at the heritage sites were interviewed. Some informants were even interviewed many times to check the validation of the findings of field, and even to cross-link the findings in interview with other key informants.

Scope and Limitations: The findings of the study were based on the research on three durbar squares of the Kathmandu Valley, and may differ for the other monument sites. As for the three durbars, the context was similar, and settings were also more or less same. For the detail analysis of KVHHS, all the seven monument zones must be taken into consideration as other four sites have different settings. The researcher did not take the other four sites in the study. Further study of the four remaining sites is necessary.

\section{Findings}

Management of Heritage Sites, Rules and Regulations:

Before the Kathmandu Valley was recognized as a WHS, Nepal has already paved the ways of conservation by introducing Ancient Monument Preservation Act (AMPA) in 1956 AD. The Ancient Monument Preservation Rules were later enforced from $1988 \mathrm{AD}$. The AMPA has classified the ancient monuments from the viewpoint of ownership as public and private. ${ }^{1}$ It had assigned the Department of Archeology (DoA) as a concerned government authority responsible to conserve, maintain and renovate public monuments, and owners themselves in the case of private monuments. In case of private monuments, some strict provisions were also formulated. Any act of demolition, maintenance and renovation of the private

${ }^{1}$ Article 3 A (1), Ancient Monument Preservation Act 2013 (1956 AD) Fifth Amendment 2052 (1995AD) 
monument requires approval from the DoA. ${ }^{2}$ In case of disobedience, he/she shall be punished fine worth Rupees Ten thousand $(\mathrm{Rs} 10,000)$ to one lakh $(\mathrm{Rs} 100,000)$ or imprisonment not exceeding six months or the both. ${ }^{3}$ The government can purchase the private monument if it deems necessary to conserve the monument. ${ }^{4}$ A transfer of ownership of these monuments other than to the government of Nepal can be restricted. ${ }^{5}$ The government has exempted house and land tax on the private ancient monuments. ${ }^{6}$ But none of these rules are seen to be enforced in practice. The interference of government in the private houses with traditional values in WHS are not recorded till now though there is provision to take the house by government and renovate it.

Other than the private monuments, AMPA prohibits construction of private houses or repairing, altering and reconstructing of existing houses within the Preserved Monument Area. An approval is required from DoA in addition to that of the concerned municipality. ${ }^{7}$ But local people have got different views regarding the renovations. Few people say it is necessary to get the approval even for the renovation; few say it depends upon the extent of renovation. Some others say it is not necessary to take approval for the renovation. The lack of clear information in the renovation is creating confusion and also giving excuse for the law breakers. The locals seem to be aware of the process of rebuilding of houses compared to the renovation. This is because DoA has kept information regarding the former in all the seven sites of KVWHS, and also peoples are interested in the benefits of rebuilding. DoA had introduced the by-laws for the reconstruction of the private house. Also

\footnotetext{
${ }^{2}$ Article 3C (2), Ancient Monument Preservation Act 2013

${ }^{3}$ Article 3C (4), Ancient Monument Preservation Act 2013

${ }^{4}$ Article 4 (1) and 7 (1), Ancient Monument Preservation Act 2013 Third amendment 2043 and Fifth amendment 2052

${ }^{5}$ Article 5 (2) (c), Ancient Monument Preservation Act 2013 (1956)

${ }^{6}$ Article 3F, Ancient Monument Preservation Act 2013 (1956)

${ }^{7}$ Article 3 (6) \& (7), Ancient Monument Preservation Act 2013 (1956)
} 
local people seem to be more interested in the reconstruction than renovation. Most of the newly built houses in WHS have used concrete, iron rods, steels which are not the authentic style. The DoA is flexible with this as long as the house is covered with the traditional materials from outside. But experts do not agree with the new flexible rules adopted by DoA, as they see the threat of losing authentic Newari architecture.

Further, any construction work includes electricity, telephone, water, sewage, road, buildings and any deeds are restricted within the preserved monument areas, and they require prior approval from the Department (DoA). ${ }^{8}$ The AMPA has provision to formulate various committees to conserve the ancient monuments and undertake survey and classify these monuments. ${ }^{9}$ These committees lack representation of local people residing nearby the monuments. ${ }^{10}$

Besides the AMPA, the Local Self Government Act (LSGA) 1999, the Town Development Act 1988 and the Guthi Corporation Act 1964 are other major legal instruments that deal with management of WHS of the Kathmandu Valley. The LSGA 1999 is the principal act for the decentralization of powers to the District Development Committees (DDC), the municipalities and the Village Development Committees (VDC). The LSGA gives the elected local government bodies the function and duty to varying degree to record, maintain and preserve the tangible and intangible heritage within their area of jurisdiction. ${ }^{11}$ Under the LSGA, the respective municipality is given the mandatory function and duty to prepare an inventory of the culturally significant places and to maintain and protect them within its territory.

\footnotetext{
${ }^{8}$ Article 3 (5), Ancient Monument Preservation Act 2013 (1956)

${ }^{9}$ Article 3(G) (1), Ancient Monument Preservation Act 2013 (1956 AD)

${ }^{10}$ Chapter 2 and 3, Ancient Monument Preservation Rules 2046 (1989)

${ }^{11}$ Article 96 (e) (2) and 96 (i) (2), Local Self Governance Act 1999
} 
The Town Development Act (TDA) 1988 mainly deals with the reconstruction, extension and development of towns, fixing land-use zones, preparing by-laws, demolishing unauthorized construction and setting standards for physical development of the town. Under this Act the Kathmandu Valley Town Development Committee (KVTDC) was formulated to undertake the above mention activities.

Many monuments and historic buildings located within the WHS belong to Guthi (traditional community-based trusts with legal ownership of most religious monuments). The Guthi Corporation Act 1964 was enacted to nationalize all Guthis to a centrally organized unit, the Guthi Sansthan. The Act further defined the Guthi Sansthan's duties to perform religious rites and festivals, preserve cultural heritage, monuments and other religious buildings, and preserve ancient ornaments and article of religious and cultural importance.

The official procedures for restoration/construction permissions are complicated and ineffective (DoA, 2007). Local residents (private owners) have to get approval both from concerned municipality office and DoA to restore/construct house within the WHS. It is quite confusing for them as there is no clear understanding of what 'acceptable change' is in respect to the $\mathrm{WH}$ areas, especially considering the controlled development of private property (ibid). Further, dual jurisdiction of different law enforcement agencies makes the process complicated. Those interviewed find getting approval from these institutions troublesome and time consuming. Hence, local residents are not willing to comply with the existing legal provisions and therefore undertake restoration/ construction activities of their house illegally. Taking permission from DoA and Municipality is adding up the official procedure for the local people. There is not only one institution to look after the overall management and monitoring of WHS so that the process and actions against the law offenders are taken fast.

Many private owners interviewed reported preserving the ancient buildings was very costly and they could not afford to 
reconstruct or build the house in traditional styles. Price of bricks and wood had increased, and also skilled human resources for maintenance were scarce and costly. Traditional knowledge on such craftsmanship had also declined over the past decade. In many cases these have actually led to demolition, and reconstruction of heritage buildings with design adapted to the by-laws that are officially valid for newly constructed buildings. Current incentives on private buildings are not adequate to attract the owners to renovate or reconstruct the buildings as per the standards prescribed in the by-laws. Bhaktapur Municipality's free Dachi Aapa (polished bricks) for the construction of private houses seems to be the initiative in support of locals but it too has been criticized by experts as favoring reconstruction instead of conservation of old buildings. Locals are also not satisfied with the initiative as a tedious and insufficient programme. Most funding agencies do not cater to private buildings. Rajbhandari House and Newa Chhe are the two successful examples of the private houses being funded by UNESCO in Patan. During the study no remarkable support by the Government or Municipality is seen in the case of private houses which are a major contributor in maintaining the traditional urban landscape.

During the study, it was seen that for the private buildings in WHS by-laws were prepared by DoA, and also for making any changes in the house or reconstruction approval from the DoA is a must. But with so much responsibility for implementing rules and regulations, DoA is not able to fulfill its tasks. The monitoring mechanism and punishment for not complying with the rules and regulations are very weak. The officials of DoA also accept the fact that due to the less manpower and limited resources monitoring and implementation has not been effective. In addition to that, DoA does not give permission to reconstruct the house which are in good condition. So, the house owners, instead of taking care of a degrading house, let it degrade furthermore and go for approval for reconstruction later. Lack of awareness and incentives for the renovation is creating a tension between house-owners and government officials. The increasing trend of reconstruction over renovation 
is threatening the authenticity of these monument zones in WHS. In addition to that, once the house is demolished it cannot be rebuilt to its original architecture.

Every house is different from the other in WHS built in the different time period. An expert like Mr. Rohit Ranjitkar does not agree with the government rule to introduce the same bylaws for all houses in WHS. The by-laws adopted a single blanket approach to conservation of private houses in the WHS instead of adopting flexible mechanism for addressing the issues of local residents. This only eases the jobs of the public authorities.

\section{Conflict and Collaboration}

Many cases of conflicts and dissatisfaction came in light in the research. These conflicts are mainly due to lack of participation of local residents in managing WHS, inadequate policy provisions to address preservation of private monuments and building within WHS and overlapping authorities and responsibilities among multiple institutions managing WHS.

People are always fascinated by newness and want for the new thing is not an odd case. So, with the changing lifestyle the house owners also wanted a modern lifestyle with cables, solar panels, underground water tanks, roof-top tanks and as such which WHS rules do not approve. With these conflicting interests, disobediences of rules and regulations take place which lead to loss of the unique heritage.

Local people feel that only enforcing laws without any benefits will not motivate them for conservation. They claim that local municipality is earning foreign currency by showing the houses of locals but the locals themselves are not getting any benefits from them. The researcher came across a number of locals dissatisfied with the rules and regulations. One such person is Mr. Chandan Sharma, a local resident of ward no. 13 at Bhaktapur Durbar Square. A teacher by profession, Sharma is fully aware of the importance of heritage. He owns a beautiful 
traditional house but expresses that its maintenance cost is expensive. He is not able to generate any income from the house since all of its space is required for his family members. The house is being an extra burden for him and his family. Except the free Dachi Appa, Bhaktapur Municipality has not initiated any benefit sharing mechanism.

Most of the monuments in WHS are in good conditions as these monuments get grants from donor agencies. The three palaces are converted into museums which are also collecting entry fees from the visitors. DoA also feels the management of WHS should be handed to the concerned municipality as they are the ones collecting fees. Thus, according to the DoA authorities monitoring, grievances handling, and giving incentives should be done by the respective municipalities.

Among the three Durbar Squares, Bhaktapur (Layaku) seems to be in the good condition. Local people of Bhaktapur seem to have much knowledge on conservation. During the study, it was found that the site manager had more interaction with the locals. People also have realised the importance of conservation but they also demand for incentives. The locals of Bhaktapur Dubar Square have decided not to sell their houses to outsiders. This also may be the reason for the intactness of urban space as every resident is the people born and brought up with the Newari tradition and surroundings only.

Hanuman Dhoka World Heritage Site is much affected by modernization and haphazard development. High land value and being the posh area near the commercial hub (New Road) is also the main reason for the emergence of high-rise buildings in its vicinity. Some new houses were rebuilt with the traditional outer façade in house but no renovated houses were seen. Also, due to the power play many people are violating the regulations of WHS, and also encroaching it. These types of cases are seen in all the three sites. One of the examples is the encroachment of Krishna Mandir, a beautiful octagonal temple at Kathmandu Hanuman Dhoka Durbar Sqaure. A portion of the temple was encroached by the attached house due to which a complete 
movement round the temple was not possible. As the house owner had a relation with the ex-royals, DoA officials also were in pressure every time the issue was raised. Later, local residents took the initiatives and demolished the wall partially, but still rest of the steps are inside the wall. The case was filed against the Department of Archaeology (DoA), but still the encroached portion of the monument is inside the wall.

Some good cases of conservation came out during the research. Some of the houses which were renovated are used by the owner to operate restaurants and lodge. Newa Chhe and Rajbhandari House are very interesting projects funded by UNESCO. These houses were renovated in the same antique style. They are now operating as a Bed \& Breakfast restaurants respectively by the house owners. Following these, encouraging number of individuals have renovated their houses and run restaurants and lodge in Patan. Thus, it can be concluded that people can be motivated for conservations by ensuring financial incentives to them.

In addition to incentives for conservation, punishment for the law offenders must be introduced. Local people share that people with political linkages also get their jobs done quickly, and in addition to that they were the ones offending the laws. Such cases of non-action were documented in the research like the case of a house attached to Krishna Mandir in Hanuman Dhoka Durbar Square and also many other non-documented cases were observed during the study where the local people were not willing to give information regarding it. This nonaction will encourage locals not to comply with rules and regulations.

\section{Conclusion and Recommendation}

KVWHS is a unique heritage site which is giving Nepal an identity in the international level. The new development and needs of the people are inevitable as the society is always in constant change. Review of national and international rules and regulations shows that multiple institutions are responsible for 
managing the WHS, but the functions, duties and roles of these institutions are not clear and are often overlapping. Existing legal provisions largely focus on preservation of public monuments, but less priority for private monuments within WHS. The laws impose the responsibility of preservation of private monuments to the owners. The private owners are conditioned to follow some strict provisions but without adequate incentive to conserve their properties. Because of this and inadequate monitoring from the Department of Archaeology, local residents very often did not comply with these legal provisions. Non-compliance is identified especially in case of construction activities like building new houses or retrofitting the existing houses. Moreover, local people are not getting opportunities of participation in various decisionmaking committees formed to manage WHS.

It is a human behavior to be motivated by incentives. The locals playing a major role in conservation should be well-recognized by giving them incentives to their good work. Similarly, punishment should be imposed on the violators of rules. In partnership with local peoples, the heritage needs to be conserved. The concerned authority should provide initiatives to involve local people in formulation and implementation of policies and plans for these sites. As international conventions also promote for all-level participation, the locals and stakeholders should be involved in conservation process.

Preservation of both public and private properties is essential for maintaining the authenticity and originality of WHS of the Kathmandu Valley. In order to minimize conflicts between the local residents and heritage management authorities, clear legal and institutional provisions addressing interests of owners of private properties need to formulated and effectively implemented. 


\section{References}

Amatya, S. (2007). Monument conservation in Nepal: My experience with the World Heritage Sites of Kathmandu Valley. Kathmandu: Vajra Publications.

Central Bureau of Statistics (CBS). (2011). Preliminary report of national census 2011. Kathmandu: National Planning Commission secretariat, Government of Nepal.

Department of Archaelogy (DoA). (2007). Kathmandu valley world heritage site: Integrated Management Framework. Kathmandu: Ministry of Culture, Tourism and Civil Aviation, Government of Nepal.

Dijkgraaf, C. (2003). How World Heritage Sites disappear: Four cases, four threats. In Eleonore de Merode, Rieks Smeets and Carol Westrik (eds.), World Heritage papers 13, paper presented at a Conference "Linking Universal and Local Values: Managing a Sustainable Future for World Heritage", from 22-24 May, 2003.

Edorma, E.L. (2003). Linking universal and local values for the sustainable management of World Heritage Sites. In Eleonore de Merode, Rieks Smeets and Carol Westrik (eds.), World Heritage papers 13, paper presented at a Conference "Linking Universal and Local Values: Managing a Sustainable Future for World Heritage", from 22-24 May, 2003

Hutt, M. (2010). Nepal : A guide to the art and architecture of the Kathmandu Valley. New Delhi: Adroit Publishers.

International Council on Monuments and Sites (ICOMOS). (1999). Charter on the built Vernacular Heritage. Ratified by the ICOMOS $12^{\text {th }}$ general assembly. Mexico: UNESCO.

International Council on Monuments and Sites (ICOMOS). (2005). Threats to World Heritage Sites 1994-2004: An analysis. Retrieved June 27, 2011 from http://www.international.icomos.org/world_heritage/An alysis\%20of\%20Threats\%201994-2004\%20final.pdf.

Jenkins, M., Selter, E., and Subba V. (2006). Patan Durbar Square cultural portraits handbook 2. Kathmandu: UNESCO 
Levy, R. I. (1992). Mesocosm: Hinduism and the organization of a traditional Newar city in Nepal. Delhi: Motilal Banarsidass Publishers Pvt. Ltd.

McManus, R. (1997). Heritage and tourism in Ireland - an unholy alliance? Irish Geography, 30 (2), 90-98.

Pradhananga, N., and Landorf, C. (2008). Stakeholder participation at World Heritage Sites: An analysis of the past and present conservation systems of the Kathmandu Valley World Heritage Site. Retrieved August 17, 2011 from http://www.guthiaustralia.org/files/Full\%20Paper\%20H eritage\%202008.pdf.

The Government of Nepal (GoN). (1999). Local Self Governance Act 1999. Retrieved Sept. 20, 2011 fromhttp://www.lawcommission.gov.np/en/documents/ prevailing-laws/prevailing-rules/func-startdown/131/.

The Government of Nepal (GoN). (2003a). Ancient Monument Preservation Act 2013 (1956). Kathmandu: Department of Archeology, Government of Nepal.

The Government of Nepal (GoN). (2003b). Ancient Monument Preservation Rules 1988. Kathmandu: Department of Archaeology, Government of Nepal.

United Nations Educational, Scientific and Cultural Organization (UNESCO). (1972). Convention concerning the protection of the world cultural and natural heritage. Paris: World Heritage Center UNESCO.

UNESCO, (1979). Convention concerning the protection of the world cultural and natural heritage. World Heritage Committee Third Session. Paris: World Heritage Center UNESCO.

UNESCO, (1999). Convention concerning the protection of the world cultural and natural heritage. World Heritage Committee Twenty Third Session. Paris: World Heritage Center UNESCO.

UNESCO. (2004). Compilation of World Heritage Committee and bureau decisions taken between 1992 - 2003 concerning Kathmandu Valley world heritage 
propriety. Kathmandu: World Heritage Center UNESCO.

UNESCO, (2005). World Heritage Centre Vienna Memorandum on "World Heritage and Contemporary Architecture - Managing the Historic urban landscape". Retrieved November 25, 2011 from http://www.icomos.fi/vienna_memorandum_comments opr.pdf.

UNESCO, (2006). Heritage homeowner's preservation manual. Kathmandu Valley World Heritage Site, Nepal. Kathmandu: UNESCO.

UNESCO, (2008). Operational guidelines for the implementation of the World Heritage Convention. Paris: World Heritage Center UNESCO.

Upreti, B.R. (2004). The price of Neglect: From resource conflict to Maoist insurgency in the Himalayan Kingdom. Kathmandu: Bhrikuti Academic Publication. 